DOI: 10.20472/IAC.2018.036.003

\author{
JANA BÉREŠOVÁ \\ University of Trnava, Slovak Republic
}

\title{
FAMILIARIZATION ACTIVITIES - ACHIEVING A GOOD UNDERSTANDING OF THE CEFR LEVELS AND DESCRIPTORS
}

\begin{abstract}
:
The Common European Framework of Reference for Languages: Learning, teaching, assessment (CEFR) integrates concepts related to target language learning/teaching and assessment from a number of different theoretical studies and focuses on meaningful target language use in real-life situations. The six-level framework with positively worded 'can do' statements refers to performances validated for particular proficiency levels. The CEFR includes many descriptor scales to encourage language users to develop differentiated profiles. The main function of descriptors is to help align language curricula, teaching and assessment, selecting illustrative descriptors according to educators' relevance to the particular context. To relate local language curricula, teaching and assessment to the CEFR, a group of local experts need to be aware of reference levels and illustrative samples to start validating their claims. A good understanding of the CEFR levels and descriptors can be achieved through familiarization activities. Their effectiveness will be discussed and analysed in the presentation and paper.
\end{abstract}

\section{Keywords:}

CEFR, familiarization, CEFR levels, descriptors, illustrative samples,

JEL Classification: $129, \mathrm{C} 18,128$ 


\section{Introduction}

Although the Common European Framework of Reference for Languages: Learning, teaching, assessment (Council of Europe, 2001) has influenced a number of language curricula and language examinations all over the world, reference levels and illustrative descriptors are perceived quite variously in different local contexts. There are several reasons based on local educational history or language policy that might be quite significant for countries' decision referring to the intensity of language education. Most European countries officially claim aligning their language curricula and national language examinations and tests with the CEFR. The CEFR introduces a concept of language learning/teaching that reflects using language in real life. Therefore, overall language proficiency is viewed as a combination of general competences and communicative language competences (linguistic, sociolinguistic and pragmatic), complemented by communicative language activities and strategies that are presented under four modes of communication: reception, production, interaction and mediation (Council of Europe, 2017). The CEFR regards learners as language users and social agents, and thus language is perceived as a medium of communication rather than a subject to study. Thus communicative language competence is described in 'can do' statements, focusing on communicative abilities of language learners and their acting in real-life situations. However, a number of national curricula focus on knowledge rather than communicative language competence and that particular knowledge is tested in the national language examinations as well.

Since the launch of the CEFR tens of countries have shown their interest in relating their national curricula and examinations to the CEFR, which required a need to help curricula writers and examination providers to develop, apply and report particular procedures helpful in demonstrating the validity of their claims. In 2008, the Council of Europe presented a manual to be used to establish a link between local curricula and examinations and the common reference levels of language proficiency (A1-C2) in a reliable way, providing both theoretical and empirical evidence. The Manual (2009) presents five interrelated sets of procedures that are advised to be followed if any institution is inclined to make claims about the relationship of either their curricula or examinations to the reference levels of the CEFR. While the first stages (familiarization, specification, standardization/benchmarking and standard setting) activities can be envisaged as arranged in chronological order, validation is a continuous process of quality monitoring that has to start from the very beginning.

Familiarization activities are necessary to be followed as a self-audit of the coverage of the examination concerning content and tasks types (specification) is based on improving the quality of the examination. National tests are based on official test specification, yet the examination in practice may not be aligned to it. Official examination specification may not be revised for some years and a self-audit is intended to raise awareness 
concerning constructs tested in the examination. As far as holistic judgements by examiners or examination performance results are concerned, standardization training and benchmarking must be introduced with familiarization activities as they enable a categorization of examination takers in terms of the proficiency levels of the CEFR.

Despite the fact that the Manual was aimed at providing a guide specifically focused on procedures involved in the justification of a claim that a particular test or examination is linked to the CEFR, it covers a broad range of activities that are useful for language educators who consider the philosophy behind the CEFR relevant for their local context. In this case, a thorough understanding of the CEFR levels and illustrative descriptors can be achieved through familiarization activities.

\section{Familiarization}

In terms of the CEFR, the word familiarization refers to an in-depth knowledge of the reference levels and illustrative samples that are used in a variety of descriptive scales in four modes of communication: reception, production, interaction and mediation. In general, language professionals in local contexts have become aware of the CEFR and are predominantly familiar with global CEFR scales. Nevertheless, their awareness of the salient features of language proficiency in different skills might be influenced by their teaching experience and they may not have a clear picture of the level of proficiency their country expects language learners to achieve in the end of schooling, applying for special jobs, studying at universities, etc. While in some countries the level of English expected to be achieved in the end of secondary school education at secondary grammar schools is B2 (for example, Slovenia, Slovakia, Croatia), other countries have their preferences in B1 for a basic level and B2 for an advanced level of school-leaving examinations (for example, the Czech Republic). These expectations are based on local language policy which is influenced by the location of the country, its population, industrial orientation, etc. Whichever CEFR level the country intends their examinations/curricula to be based on, the process of linking the tests/examinations to the CEFR should be grounded in theoretical and practical evidence, which requires to invite language professionals (policymakers, language developers, curricula developers, item writers, language teachers) to make decisions that need to be fair, valid and efficient as they may influence life of young people or adults significantly. To arrive at fair and defensible decisions, language professionals should become panelists in the training workshops, on account of the fact that they can use their previous experience and knowledge. The goal of the familiarization workshop is to harmonize and broaden their perception of language learning, teaching and assessment, laying great emphasis on an action-oriented approach supported by the CEFR. These panelists are provided with specific activities related to the process of aligning tests/examinations/curricula to the CEFR. 


\subsection{Global scales}

The aim of familiarization activities is to introduce a list of scales that are appropriate for a local context. However, it is recommended to start with more global scales such as selfassessment grid (Appendix A) which may be presented to the participants of the familiarization workshop for:

a) self-assessing their abilities in target languages or

b) reconstructing the table, in which cells related to a particular skill (due to country's preferences, and expected, desired or planned proficiency levels) might be chopped up and participants are expected to match the chopped-up cells in the place they fit in the table.

Both activities prepare the participants to get a clear picture that language learners have usually uneven levels of language proficiency as they use target languages for different purposes, for example, students of medicine or doctors need English for reading about latest advances in medicine, while company managers need languages for presentations, interaction (negotiation, formal discussion in the meetings, goal-oriented co-operation etc.).

The most frequently used table is the one based on salient characteristics concerning interaction and production (Appendix B). As mentioned before, most language users are better at receptive skills rather than productive skills. On the contrary, accomplishing tasks related to speaking and writing enables assessors to get information about learners' competences and what a learner is able to do in the language. The table can be used for:

a) indicating a proficiency level on the basis of the description of salient features that are presented in a jumbled order

b) ordering strips of papers with illustrative descriptors from the lowest level to the highest level.

This task should be done in two steps. While in the first stage it is important to work with 6 basic levels (A1, A2, B1, B2, C1 and C2), in the second one three plus levels $(A 2+, B 1+$ and $\mathrm{B} 2+)$ are added and discussed. The original six or nine proficiency levels have been broadened by a new one called pre-A1 (Council of Europe, 2017). The Companion Volume with New Descriptors (Council of Europe, 2017) introduced a new approach to the whole system of reference descriptors, which resulted in a more systematic approach to plus levels. Three reference levels (A2, B1 and B2) are mostly divided into two bands, out of which a top band is considered a plus level of the main reference level (Table 1). This conceptual distinction enables panelists to recognize slight differences within one reference level and become aware of a necessity to read illustrative descriptors carefully, focusing on particular words that might bear a significant meaning for distinguishing those two closely related bands within one level. 
Table 1: Overall spoken production (Council of Europe, 2017: 81)

\begin{tabular}{|l|l|}
\hline \multirow{2}{*}{ B2 } & $\begin{array}{l}\text { Can give clear, systematically developed descriptions and presentations, with appropriate } \\
\text { highlighting of significant points, and relevant supporting detail. }\end{array}$ \\
\cline { 2 - 3 } & $\begin{array}{l}\text { Can give clear, detailed descriptions and presentations on a wide range of subjects } \\
\text { related to his/her field of interest, expanding and supporting ideas with subsidiary points } \\
\text { and relevant examples. }\end{array}$ \\
\hline
\end{tabular}

After completing one of the tasks, the participants of the familiarization workshop are expected to work in pairs or groups focusing on different reference levels highlighting key elements, writing them on a sheet of paper that is later presented in front of the others that are expected to complete the list of key words. All these posters are tagged on the wall to enable panelists to be exposed to salient features all the time during the workshop. These short presentations make panelists compare the wording of particular levels and help them discover similar words for the same level in different scales such as single, isolated phrases and sentences for $\mathrm{A} 1$, a series of simple phrases and sentences for A2, straightforward for B1, clear, detailed texts for B2, well-structured texts for $\mathrm{C} 1$, and clear, smoothly flowing texts for $\mathrm{C} 2$ for written production.

While three modes (reception, production and interaction) are represented by a number of specific scales, the fourth called mediation has been developed and validated recently. Several institutions all over the world participated in the project, held in 2015-2016, Trnava University in Slovakia including. Mediation is viewed as a mode of communication in which language learners as social agents help other users of the same language or different languages to construct and convey meaning. New meanings are constructed in collaboration with other partners of communication.

\subsection{Specific scales}

Language learners learn target languages for their own specific purposes. Their preferences are based on their choice of a particular school/university or their (future) jobs. Reception activities embrace listening comprehension and reading comprehension, while production activities include spoken production and written production as counterparts to interaction activities comprising spoken interaction and spoken production. As mentioned above, doctors might need reading skills that refer to reading for information and argument. Some technical professionals might use reading in a target language only for getting instructions, therefore the specific scale called Reading instructions seems to be very useful for either their language courses or language examinations. The results achieved in a particular proficiency test can be used as proof of competence for job applications. 
Table 2: Communicative language activities in three modes of communication

\begin{tabular}{|c|c|c|c|c|c|}
\hline \multicolumn{2}{|l|}{$\begin{array}{l}\text { Reception } \\
\text { Activities }\end{array}$} & \multicolumn{2}{|l|}{$\begin{array}{l}\text { Production } \\
\text { Activities }\end{array}$} & \multicolumn{2}{|l|}{$\begin{array}{l}\text { Interaction } \\
\text { Activities }\end{array}$} \\
\hline $\begin{array}{l}\text { Listening } \\
\text { comprehension }\end{array}$ & $\begin{array}{l}\text { Reading } \\
\text { Comprehension }\end{array}$ & $\begin{array}{l}\text { Spoken } \\
\text { Production }\end{array}$ & $\begin{array}{l}\text { Written } \\
\text { Production }\end{array}$ & $\begin{array}{l}\text { Spoken } \\
\text { Interaction }\end{array}$ & $\begin{array}{l}\text { Written } \\
\text { Interaction }\end{array}$ \\
\hline $\begin{array}{l}\text { Understanding } \\
\text { interaction } \\
\text { between other } \\
\text { speakers }\end{array}$ & $\begin{array}{l}\text { Reading } \\
\text { correspondence }\end{array}$ & $\begin{array}{l}\text { Sustained } \\
\text { monologue: } \\
\text { describing } \\
\text { experiences }\end{array}$ & $\begin{array}{l}\text { Creative } \\
\text { writing }\end{array}$ & $\begin{array}{l}\text { Understanding } \\
\text { the interlocutor }\end{array}$ & $\begin{array}{l}\text { Corresponde } \\
\text { nce }\end{array}$ \\
\hline $\begin{array}{l}\text { Listening as a } \\
\text { member of a } \\
\text { live audience }\end{array}$ & $\begin{array}{l}\text { Reading for } \\
\text { orientation }\end{array}$ & $\begin{array}{l}\text { Sustained } \\
\text { monologue: } \\
\text { giving } \\
\text { information }\end{array}$ & $\begin{array}{l}\text { Written } \\
\text { reports and } \\
\text { essays }\end{array}$ & Conversation & $\begin{array}{l}\text { Notes, } \\
\text { message and } \\
\text { forms }\end{array}$ \\
\hline $\begin{array}{l}\text { Listening to } \\
\text { announcements } \\
\text { and instructions }\end{array}$ & $\begin{array}{l}\text { Reading for } \\
\text { information and } \\
\text { argument }\end{array}$ & $\begin{array}{l}\text { Sustained } \\
\text { monologue: } \\
\text { putting a case } \\
\text { (e.g. debate) }\end{array}$ & & $\begin{array}{l}\text { Informal } \\
\text { discussion }\end{array}$ & \\
\hline \multirow[t]{6}{*}{$\begin{array}{l}\text { Listening to } \\
\text { radio and audio } \\
\text { recordings }\end{array}$} & $\begin{array}{l}\text { Reading } \\
\text { instructions }\end{array}$ & $\begin{array}{l}\text { Public } \\
\text { announcements }\end{array}$ & & $\begin{array}{l}\text { Formal } \\
\text { discussion } \\
\text { (meetings) }\end{array}$ & \\
\hline & $\begin{array}{l}\text { Reading as a } \\
\text { leisure activity }\end{array}$ & $\begin{array}{l}\text { Addressing } \\
\text { audiences }\end{array}$ & & $\begin{array}{l}\text { Goal-oriented } \\
\text { co-operation }\end{array}$ & \\
\hline & & & & $\begin{array}{l}\text { Obtaining } \\
\text { goods } \\
\text { services }\end{array}$ & \\
\hline & & & & $\begin{array}{l}\text { Information } \\
\text { exchange }\end{array}$ & \\
\hline & & & & $\begin{array}{l}\text { Interviewing } \\
\text { and being } \\
\text { interviewed }\end{array}$ & \\
\hline & & & & $\begin{array}{l}\text { Using tele- } \\
\text { communications }\end{array}$ & \\
\hline
\end{tabular}

Source: Adapted from the CEFR

From the overview presented in Table 2, it is possible to conclude that a diversity of scales enables language professionals to focus on specific scales that might be used in familiarization training in their local context. The scales are optional and serve real-life purposes, for example, economists need to be skillful in putting a case, addressing audiences, discussing particular issues in meetings, etc., therefore language curricula and tests should include the scales that suit educational objectives for future economists.

There are several activities related to specific scales that can attract panelists. Matching tasks are very useful as they enable panelists, who indicate which particular level 
matches which reference level, to discuss particular descriptors and exact wording. This approach supports a detailed understanding of the CEFR. Every scale embraces key concepts that are operationalized in it. The consistent stand is taken on development of strategies. While only one scale is provided for reception strategies (identifying cues and inferring) based on understanding through a combination of bottom-up and top-down processing of the text either written or spoken, production strategies comprise three scales: planning, compensating, monitoring and repair. Interaction strategies embody taking the floor (turn-taking), co-operating and asking for clarification. Curricula developers might incorporate these strategies into the language learning program and familiarization activity might be based on matching reference levels to descriptors that are not in chronological order.

Table 3: Communicative language strategies - an activity

\begin{tabular}{|l|l|}
\hline ASKING FOR CLARIFICATION (A2-B2) \\
\hline Can ask very simply for repetition when he/she does not understand \\
\hline Can ask someone to clarify or elaborate what they have just said. \\
\hline Can ask for clarification about key words or phrases not understood using stock phrases. \\
\hline $\begin{array}{l}\text { Can ask follow-up questions to check thathe/she has understood what a speaker intended to say, and get } \\
\text { clarification of ambiguous points. }\end{array}$ \\
\hline Can say he/she didn't follow \\
\hline
\end{tabular}

Source: Adapted from the CEFR

In this activity, panelists are expected to indicate reference levels. Despite the fact that the number of descriptors is five, the participants may use only three levels $(A 2, B 1$ and B2) out of which one or two might be represented by more descriptors. This requires intensive reading, linking the key words from general scales to more specific ones.

The fourth mode (mediation) covers social, pedagogic, cultural, linguistic or professional contexts and is elaborated in three groups of scales concerning mediation activities (mediating a text, mediating concepts and mediating communication) and two groups of mediation strategies (strategies to explain a new concept and strategies to simplify a text). These five groups are further refined into several scales (Council of Europe, 2017).

\section{Conclusion}

As mentioned before, familiarization activities might be organized separately or before undertaking other stages of the linking processes (specification and standardization) and therefore those who are involved in the training process sometimes seem to be overwhelmed by different activities they have to deal with. To practice indicating CEFR levels is worth doing as participants are naturally exposed to repetition of certain key concepts and key words, and later they immediately can recognize a particular level. However, it is necessary to mention that not all the scales use the same wording. Despite 
the fact that it does not occur frequently, it might mislead those who focus too strictly on the wording of descriptors and follow them blindly without analyzing exact meanings.

Doubtless familiarization activities are of high importance. Most professionals involved in language teaching and testing are more familiar with global CEFR scales. The most common is the scale with salient characteristics for interaction and production (Appendix C) that is used in the very beginning of the training session when panelists are to identify the salient features for each level and to ascertain at which level they would place the language learners they work with. Participants are expected to share their views in pairs or groups and each group is asked to highlight key elements of one of the levels. Their posters are presented on a visible place and anybody can add other typical features verified in the CEFR. This activity is used either as preparatory when the work is done individually before the training workshop or as an introductory activity, as mentioned above. On the other hand, it might be used as an ice-breaker to link the workshop activities with pre-seminar work.

Familiarization activities enable the participants of the training workshop to get a clear picture of communicative language competence and proficiency levels introduced by the CEFR as they might be influenced by local institutional standards or locally produced variants of CEFR descriptors. Despite the fact that the original aim of organizing a familiarization workshop was to provide an introduction to the process of relating an examination or curricula to the CEFR, it can serve as a regular teacher training seminar in which participants are equipped with sufficient awareness of the CEFR levels and descriptors to analyze their students' performances in relation to the CEFR levels. It is necessary to retake the activities in case the panelists/participants are inconsistent in the content analysis of language curricula/examinations or in judgements in standardization or standard-setting procedures. Familiarization activities are worth going through properly and different scales can only enrich awareness of the CEFR sufficiently.

\section{Reference}

COUNCIL OF EUROPE (2001). A Common European Framework of Reference for Languages: Learning, teaching, assessment. $1^{\text {st }}$ edition. Cambridge: Cambridge University Press. 2001.

COUNCIL OF EUROPE (2009). Relating language examinations to the Common European Framework of Reference for Languages: Learning, teaching, assessment (CEFR). A Manual. Strasbourg: Language Policy Division.

COUNCIL OF EUROPE (2017). Common European Framework of Reference for Languages: Learning, teaching, assessment. Companion Volume with New Descriptors. Provisional edition. Strasbourg: Education Policy Division. 2017.

NOIJONS, J., BÉREŠOVÁ, J., BRETON, J. and SZABÓ, G. (2011). Relating language examinations to the Common European Framework of Reference for Languages: Learning, teaching, assessment (CEFR). Highlights from the Manual. 1st ed. Graz: ECML / Council of Europe. 
Appendix A: Table 2 Common reference

from Highlights (Noijons et al., 2011).

levels: Self-assessment grid. Adapted

\begin{tabular}{|c|c|c|c|c|c|c|}
\hline & A1 & A2 & B1 & B2 & C1 & $\mathrm{C} 2$ \\
\hline : & $\begin{array}{l}\text { I can understand } \\
\text { familiar words and very } \\
\text { basic phrases } \\
\text { concerning myself, my } \\
\text { family and immediate } \\
\text { concrete surroundings } \\
\text { when people speak } \\
\text { slowly and clearly. }\end{array}$ & $\begin{array}{l}\text { I can understand phrases } \\
\text { and the highest frequency } \\
\text { vocabulary related to areas } \\
\text { of most immediate } \\
\text { personal relevance (e.g. } \\
\text { very basic personal and } \\
\text { family information, } \\
\text { shopping, local area, } \\
\text { employment). I can catch } \\
\text { the main point in short, } \\
\text { clear, simple messages } \\
\text { and announcements. }\end{array}$ & $\begin{array}{l}\text { I can understand the } \\
\text { main points of clear } \\
\text { standard speech on } \\
\text { familiar matters } \\
\text { regularly encountered } \\
\text { in work, school, leisure, } \\
\text { etc. I can understand } \\
\text { the main point of many } \\
\text { radio or TV } \\
\text { programmes on } \\
\text { current affairs or topics } \\
\text { of personal or } \\
\text { professional interest } \\
\text { when the delivery is } \\
\text { relatively slow and } \\
\text { clear. }\end{array}$ & $\begin{array}{l}\text { I can understand } \\
\text { extended speech and } \\
\text { lectures and follow } \\
\text { even complex lines } \\
\text { of argument provided } \\
\text { the topic is } \\
\text { reasonably familiar. I } \\
\text { can understand most } \\
\text { TV news and current } \\
\text { affairs programmes. I } \\
\text { can understand the } \\
\text { majority of films in } \\
\text { standard dialect. }\end{array}$ & $\begin{array}{l}\text { I can understand } \\
\text { extended speech } \\
\text { even when it is not } \\
\text { clearly structured and } \\
\text { when relationships } \\
\text { are only implied and } \\
\text { not signalled } \\
\text { explicitly. I can } \\
\text { understand television } \\
\text { programmes and } \\
\text { films without too } \\
\text { much effort. }\end{array}$ & $\begin{array}{l}\text { I have no difficulty in } \\
\text { understanding any kind } \\
\text { of spoken language, } \\
\text { whether live or } \\
\text { broadcast, even when } \\
\text { delivered at fast native } \\
\text { speed, provided. I have } \\
\text { some time to get } \\
\text { familiar with the accent. }\end{array}$ \\
\hline 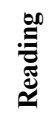 & & & & & & \\
\hline 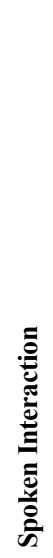 & $\begin{array}{l}\text { I can interact in a } \\
\text { simple way provided } \\
\text { the other person is } \\
\text { prepared to repeat or } \\
\text { rephrase things at a } \\
\text { slower rate of speech } \\
\text { and help me formulate } \\
\text { what I'm trying to say. I } \\
\text { can ask and answer } \\
\text { simple questions in } \\
\text { areas of immediate } \\
\text { need or on very } \\
\text { familiar topics. }\end{array}$ & $\begin{array}{l}\text { I can communicate in } \\
\text { simple and routine tasks } \\
\text { requiring a simple and } \\
\text { direct exchange of } \\
\text { information on familiar } \\
\text { topics and activities. I can } \\
\text { handle very short social } \\
\text { exchanges, even though I } \\
\text { can't usually understand } \\
\text { enough to keep the } \\
\text { conversation going } \\
\text { myself. }\end{array}$ & $\begin{array}{l}\text { I can deal with most } \\
\text { situations likely to arise } \\
\text { whilst travelling in an } \\
\text { areas where the } \\
\text { language is spoken. I } \\
\text { can enter unprepared } \\
\text { into conversation on } \\
\text { topics that are familiar, } \\
\text { of personal interest or } \\
\text { pertinent to everyday } \\
\text { life (e.g. family, } \\
\text { hobbies, work, travel } \\
\text { and current events). }\end{array}$ & $\begin{array}{l}\text { I can interact with a } \\
\text { degree of fluency and } \\
\text { spontaneity that } \\
\text { makes regular } \\
\text { interaction with } \\
\text { native speakers quite } \\
\text { possible. I can take } \\
\text { an active part in } \\
\text { discussion in familiar } \\
\text { contexts, accounting } \\
\text { for and sustaining } \\
\text { my views. }\end{array}$ & $\begin{array}{l}\text { I can express myself } \\
\text { fluently and } \\
\text { spontaneously } \\
\text { without much } \\
\text { obvious searching for } \\
\text { expressions. I can } \\
\text { use language flexibly } \\
\text { and effectively for } \\
\text { social and } \\
\text { professional } \\
\text { purposes. I can } \\
\text { formulate ideas and } \\
\text { opinions with } \\
\text { precision and relate } \\
\text { my contribution } \\
\text { skillfully to those of } \\
\text { other speakers. }\end{array}$ & $\begin{array}{l}\text { I can take part } \\
\text { effortlessly in any } \\
\text { conversation or } \\
\text { discussion and have a } \\
\text { good familiarity with } \\
\text { idiomatic expressions } \\
\text { and colloquialisms. I } \\
\text { can express myself } \\
\text { fluently and convey } \\
\text { finer shades of meaning } \\
\text { precisely. If I do have a } \\
\text { problem I can backtrack } \\
\text { and restructure around } \\
\text { the difficulty so } \\
\text { smoothly that other } \\
\text { people are hardly aware } \\
\text { of it. }\end{array}$ \\
\hline 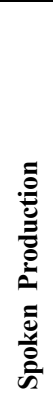 & $\begin{array}{l}\text { I can use simple } \\
\text { phrases and sentences } \\
\text { to describe where I live } \\
\text { and people I know. }\end{array}$ & $\begin{array}{l}\text { I can use a series of } \\
\text { phrases and sentences to } \\
\text { describe in simple terms } \\
\text { my family and other } \\
\text { people, living conditions, } \\
\text { my educational } \\
\text { background and my } \\
\text { present or most recent job. }\end{array}$ & $\begin{array}{l}\text { I can connect phrases in } \\
\text { a simple way in order to } \\
\text { describe experiences } \\
\text { and events, my dreams, } \\
\text { hopes and ambitions. I } \\
\text { can briefly give reasons } \\
\text { and explanations for } \\
\text { opinions and plans. I } \\
\text { can narrate a story or } \\
\text { relate the plot of a book } \\
\text { or film and describe my } \\
\text { reactions. }\end{array}$ & $\begin{array}{l}\text { I can present clear, } \\
\text { detailed descriptions } \\
\text { on a wide range of } \\
\text { subjects related to } \\
\text { my field of interest. I } \\
\text { can explain a } \\
\text { viewpoint on a } \\
\text { topical issue giving } \\
\text { the advantages and } \\
\text { disadvantages of } \\
\text { various options. }\end{array}$ & $\begin{array}{l}\text { I can present clear, } \\
\text { detailed descriptions } \\
\text { of complex subjects } \\
\text { integrating sub- } \\
\text { themes, developing } \\
\text { particular points and } \\
\text { rounding off with an } \\
\text { appropriate } \\
\text { conclusion. }\end{array}$ & $\begin{array}{l}\text { I can present a clear, } \\
\text { smoothly-flowing } \\
\text { description or argument } \\
\text { in a style appropriate to } \\
\text { the context and with an } \\
\text { effective logical } \\
\text { structure which helps } \\
\text { the recipient to notice } \\
\text { and remember } \\
\text { significant points. }\end{array}$ \\
\hline 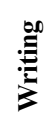 & & & & & & \\
\hline
\end{tabular}




\section{READING}

1) I can understand texts that consist mainly of high frequency everyday or job-related language. I can understand the description of events, feelings and wishes in personal letters.

2) I can understand long and complex factual and literary texts, appreciating distinctions of style. I can understand specialised articles and longer technical articles, even when they do not relate to my field.

3) I can read very short, simple texts. I can find specific, predictable information in everyday material such as advertisements, prospectuses, menus and timetables and I can understand short simple personal letters.

4) I can read with ease virtually all forms of the written language, including abstract, structurally or linguistically complex texts such as manuals, specialised articles and literary texts.

5) I can understand familiar names, words and very simple sentences, for example on notices and posters or in catalogues.

\section{WRITING}

1) I can express myself in clear, well-structured text, expressing points of view at some length. I can select style appropriate to the reading in mind.

2) I can write a short postcard, for example sending holiday greetings.

3) I can write clear, detailed text on a wide range of subjects related to my interests. I can write an essay or report, passing on information giving reasons in support of or against a particular point of view.

4) I can write smoothly flowing text in an appropriate style. I can write complex texts, summaries and reviews of professional or literary works.

5) I can write simple connected text on topics which are familiar or of personal interest.

6) I can write short, simple notes and messages relating to matters in areas of immediate need.

6) I can read articles and reports concerned with contemporary problems in which the writers adopt particular attitudes or viewpoints. I can understand contemporary literary prose. 


\section{Appendix B: ORAL ASSESSMENT CRITERIA GRID}

\begin{tabular}{|c|c|c|c|c|c|}
\hline & RANGE & ACCURACY & FLUENCY & INTERACTION & COHERENCE \\
\hline $\begin{array}{l}C \\
2\end{array}$ & $\begin{array}{l}\text { Shows great flexibility } \\
\text { reformulating ideas in } \\
\text { differing linguistic forms to } \\
\text { convey finer shades of } \\
\text { meaning precisely, to give } \\
\text { emphasis, to differentiate } \\
\text { and to eliminate ambiguity. } \\
\text { Also has a good command } \\
\text { of idiomatic expressions } \\
\text { and colloquialisms. }\end{array}$ & $\begin{array}{l}\text { Maintains consistent gram- } \\
\text { matical control of complex } \\
\text { language, even while atten- } \\
\text { tion is otherwise engaged } \\
\text { (e.g. in forward planning, in } \\
\text { monitoring others' } \\
\text { reactions). }\end{array}$ & $\begin{array}{l}\text { Can express him/herself } \\
\text { spontaneously at length } \\
\text { with a natural colloquial } \\
\text { flow, avoiding or } \\
\text { backtracking around any } \\
\text { difficulty so smoothly that } \\
\text { the interlocutor is hardly } \\
\text { aware of it. }\end{array}$ & $\begin{array}{l}\text { Can interact with ease and } \\
\text { skill, picking up and using } \\
\text { non-verbal and intonational } \\
\text { cues apparently } \\
\text { effortlessly. Can interweave } \\
\text { his/her contribution into the } \\
\text { joint discourse with fully } \\
\text { natural turn-taking, } \\
\text { referencing, allusion } \\
\text { making etc. }\end{array}$ & $\begin{array}{l}\text { Can create coherent and } \\
\text { cohesive discourse making } \\
\text { full and appropriate use of } \\
\text { a variety of organisational } \\
\text { patterns and a wide range } \\
\text { of connectors and other } \\
\text { cohesive devices. }\end{array}$ \\
\hline $\begin{array}{l}C \\
1\end{array}$ & & $\begin{array}{l}\text { Consistently maintains a } \\
\text { high degree of grammatical } \\
\text { accuracy; errors are rare, } \\
\text { difficult to spot and } \\
\text { generally corrected when } \\
\text { they do occur. }\end{array}$ & $\begin{array}{l}\text { Can express him/herself } \\
\text { fluently and spontaneously, } \\
\text { almost effortlessly. Only a } \\
\text { conceptually difficult } \\
\text { subject can hinder a } \\
\text { natural, smooth flow of } \\
\text { language. }\end{array}$ & & $\begin{array}{l}\text { Can produce clear, } \\
\text { smoothly flowing, well- } \\
\text { structured speech, showing } \\
\text { controlled use of organiza- } \\
\text { tional patterns, connectors } \\
\text { and cohesive devices. }\end{array}$ \\
\hline $\begin{array}{l}B \\
2\end{array}$ & & $\begin{array}{l}\text { Shows a relatively high de- } \\
\text { gree of grammatical } \\
\text { control. Does not make } \\
\text { errors which cause misun- } \\
\text { derstanding, and can } \\
\text { correct most of his/her } \\
\text { mistakes. }\end{array}$ & & $\begin{array}{l}\text { Can initiate discourse, take } \\
\text { his/her turn when } \\
\text { appropriate and end } \\
\text { conversation when he/she } \\
\text { needs to, though he/she } \\
\text { may not always do this } \\
\text { elegantly. Can help the } \\
\text { discussion along on familiar } \\
\text { ground confirming } \\
\text { comprehension, inviting } \\
\text { others in, etc. }\end{array}$ & $\begin{array}{l}\text { Can use a limited number } \\
\text { of cohesive devices to link } \\
\text { his/her utterances into } \\
\text { clear, coherent discourse, } \\
\text { though there may be some } \\
\text { "jumpiness" in a long con- } \\
\text { tribution. }\end{array}$ \\
\hline $\begin{array}{l}B \\
1\end{array}$ & $\begin{array}{l}\text { Has enough language to } \\
\text { get by, with sufficient } \\
\text { vocabulary to express } \\
\text { him/herself with some } \\
\text { hesitation and circumlocu- } \\
\text { tions on topics such as } \\
\text { family, hobbies and } \\
\text { interests, work, travel, and } \\
\text { current events. }\end{array}$ & $\begin{array}{l}\text { Uses reasonably accurately } \\
\text { a repertoire of frequently } \\
\text { used "routines" and patterns } \\
\text { associated with more } \\
\text { predictable situations. }\end{array}$ & & $\begin{array}{l}\text { Can initiate, maintain and } \\
\text { close simple face-to-face } \\
\text { conversation on topics that } \\
\text { are familiar or of personal } \\
\text { interest. Can repeat back } \\
\text { part of what someone has } \\
\text { said to confirm mutual } \\
\text { understanding. }\end{array}$ & $\begin{array}{l}\text { Can link a series of shorter, } \\
\text { discrete simple elements } \\
\text { into a connected, linear } \\
\text { sequence of points. }\end{array}$ \\
\hline $\begin{array}{l}\text { A } \\
2\end{array}$ & $\begin{array}{l}\text { Uses basic sentence } \\
\text { patterns with memorized } \\
\text { phrases, groups of a few } \\
\text { words and formulae in order } \\
\text { to communicate limited } \\
\text { information in simple } \\
\text { everyday situations. }\end{array}$ & $\begin{array}{l}\text { Uses some simple } \\
\text { structures correctly, but still } \\
\text { systematically makes basic } \\
\text { mistakes. }\end{array}$ & $\begin{array}{l}\text { Can make him/herself } \\
\text { understood in very short } \\
\text { utterances, even though } \\
\text { pauses, false starts and } \\
\text { reformulation are very } \\
\text { evident. }\end{array}$ & & $\begin{array}{l}\text { Can link groups of words } \\
\text { with simple connectors like } \\
\text { "and, "but" and "because". }\end{array}$ \\
\hline $\begin{array}{l}A \\
1\end{array}$ & $\begin{array}{l}\text { Has a very basic repertoire } \\
\text { of words and simple } \\
\text { phrases related to personal } \\
\text { details and particular } \\
\text { concrete situations.. }\end{array}$ & $\begin{array}{l}\text { Shows only limited control } \\
\text { of a few simple } \\
\text { grammatical structures and } \\
\text { sentence patterns in a } \\
\text { memorized repertoire. }\end{array}$ & $\begin{array}{l}\text { Can manage very short, } \\
\text { isolated, mainly pre- } \\
\text { packaged utterances, with } \\
\text { much pausing to search for } \\
\text { expressions, to articulate } \\
\text { less familiar words, and to } \\
\text { repair communication. }\end{array}$ & & $\begin{array}{l}\text { Can link words or groups of } \\
\text { words with very basic linear } \\
\text { connectors like "and" or } \\
\text { "then". }\end{array}$ \\
\hline
\end{tabular}

Source: Adapted from Highlights from the Manual (Noijons et al., 2011) 
1) Has a good command of a broad range of language allowing him/her to select a formulation to express him/ herself clearly in an appropriate style on a wide range of general, academic, professional or leisure topics without having to restrict what he/she wants to say.

2) Can produce stretches of language with a fairly even tempo; although he/she can be hesitant as he or she searches for patterns and expressions, there are few noticeably long pauses.

3) Can ask and answer questions about personal details. Can interact in a simple way but communication is totally dependent on repetition, rephrasing and repair.

4) Can select a suitable phrase from a readily available range of discourse functions to preface his remarks in order to get or to keep the floor and to relate his/her own contributions skilfully to those of other speakers.

5) Can keep going comprehensibly, even though pausing for grammatical and lexical planning and repair is very evident, especially in longer stretches of free production.

6) Has a sufficient range of language to be able to give clear descriptions, express viewpoints on most general topics, without much conspicuous searching for words, using some complex sentence forms to do so.

7) Can ask and answer questions and respond to simple statements. Can indicate when he/she is following but is rarely able to understand enough to keep conversation going of his/her own accord. 


\section{Appendix C: Salient characteristics: CEFR levels A1 to C2}

Familiarization: Indicate the level corresponding to the descriptor and justify your choice

It is at this level that the majority of descriptors stating social functions like use simple everyday polite forms of greeting and address; greet people, ask how they are and react to news; handle very short social exchanges; ask and answer questions about what they do at work and in free time; make and respond to invitations; discuss what to do, where to go and make arrangements to meet; make and accept offers. Here too are to be found descriptors on getting out and about: make simple transactions in shops, post offices or banks; get simple information about travel; use public transport: buses, trains, and taxis, ask for basic information, ask and give directions, and buy tickets; ask for and provide everyday goods and services.

What seems to characterize this level is a good access to a broad range of language, which allows fluent, spontaneous communication, as illustrated by the following examples: Can express him/herself fluently and spontaneously, almost effortlessly. Has a good command of a broad lexical repertoire allowing gaps to be readily overcome with circumlocutions. There is_little obvious searching for expressions or avoidance strategies; only a conceptually difficult subject can hinder a natural, smooth flow of language. The discourse skills characterizing the previous band are more evident here, with an emphasis on more fluency, for example: select a suitable phrase from a fluent repertoire of discourse functions to preface his remarks in order to get the floor, or to gain time and keep it whilst thinking; produce clear, smoothly-flowing, well-structured speech, showing controlled use of organizational patterns, connectors and cohesive devices.

Descriptors calibrated at this level represent a break with the content so far. Firstly there is a focus on effective argument: account for and sustain his opinions in discussion by providing relevant explanations, arguments and comments; explain a viewpoint on a topical issue giving the advantages and disadvantages of various options; develop an argument giving reasons in support of or against a particular point of view; take an active part in informal discussion in familiar contexts, commenting, putting point of view clearly, evaluating alternative proposals and making and responding to hypotheses. Secondly, at this level one can hold your own in social discourse: e.g. understand in detail what is said to him/her in the standard spoken language even in a noisy environment; initiate discourse, take his turn when appropriate and end conversation when he/she needs to, though he/she may not always do this elegantly; interact with a degree of fluency and spontaneity that makes regular interaction with native speakers quite possible without imposing strain on either party. Finally, there is a new degree of language awareness: correct mistakes if they have led to misunderstandings; make a note of "favourite mistakes" and consciously monitor speech for it/them; generally correct slips and errors if he becomes conscious of them.

This level is intended to characterize the degree of precision, appropriateness and ease with the language which typifies the speech of those who have been highly successful learners. Descriptors calibrated here include: convey finer shades of meaning precisely by using, with reasonable accuracy, a wide range of modification devices; has a good command of idiomatic expressions and colloquialisms with awareness of connotative level of meaning; backtrack and restructure around a difficulty so smoothly the interlocutor is hardly aware of it.

This level is the lowest level of generative language use - the point at which the learner can interact in a simple way, ask and answer simple questions about themselves, where they live, people they know, and things they have, initiate and respond to simple statements in areas of immediate need or on very familiar topics, rather than relying purely on a very finite rehearsed, lexically organized repertoire of situation-specific phrases.

This level is perhaps most categorized by two features. The first feature is the ability to maintain interaction and get across what you want to, for example: generally follow the main points of extended discussion around him/her, provided speech is clearly articulated in standard dialect; express the main point he/she wants to make comprehensibly; keep going comprehensibly, even though pausing for grammatical and lexical planning and repair is very evident, especially in longer stretches of free production. The second feature is the ability to cope flexibly with problems in everyday life, for example cope with less routine situations on public transport; deal with most situations likely to arise when making travel arrangements through an agent or when actually travelling; enter unprepared into conversations on familiar topics. 


\section{Appendix C: Salient characteristics: CEFR levels A1 to C2}

Familiarization: Indicate the level corresponding to the descriptor and justify your choice

It is at this level that the majority of descriptors stating social functions like use simple everyday polite forms of greeting and address; greet people, ask how they are and react to news; handle very short social exchanges; ask and answer questions about what they do at work and in free time; make and respond to invitations; discuss what to do, where to go and make arrangements to meet; make and accept offers. Here too are to be found descriptors on getting out and about: make simple transactions in shops, post offices or banks; get simple information about travel; use public transport: buses, trains, and taxis, ask for basic information, ask and give directions, and buy tickets; ask for and provide everyday goods and services.

What seems to characterize this level is a good access to a broad range of language, which allows fluent, spontaneous communication, as illustrated by the following examples: Can express him/herself fluently and spontaneously, almost effortlessly. Has a good command of a broad lexical repertoire allowing gaps to be readily overcome with circumlocutions. There is_little obvious searching for expressions or avoidance strategies; only a conceptually difficult subject can hinder a natural, smooth flow of language. The discourse skills characterizing the previous band are more evident here, with an emphasis on more fluency, for example: select a suitable phrase from a fluent repertoire of discourse functions to preface his remarks in order to get the floor, or to gain time and keep it whilst thinking; produce clear, smoothly-flowing, well-structured speech, showing controlled use of organizational patterns, connectors and cohesive devices.

Descriptors calibrated at this level represent a break with the content so far. Firstly there is a focus on effective argument: account for and sustain his opinions in discussion by providing relevant explanations, arguments and comments; explain a viewpoint on a topical issue giving the advantages and disadvantages of various options; develop an argument giving reasons in support of or against a particular point of view; take an active part in informal discussion in familiar contexts, commenting, putting point of view clearly, evaluating alternative proposals and making and responding to hypotheses. Secondly, at this level one can hold your own in social discourse: e.g. understand in detail what is said to him/her in the standard spoken language even in a noisy environment; initiate discourse, take his turn when appropriate and end conversation when he/she needs to, though he/she may not always do this elegantly; interact with a degree of fluency and spontaneity that makes regular interaction with native speakers quite possible without imposing strain on either party. Finally, there is a new degree of language awareness: correct mistakes if they have led to misunderstandings; make a note of "favourite mistakes" and consciously monitor speech for it/them; generally correct slips and errors if he becomes conscious of them.

This level is intended to characterize the degree of precision, appropriateness and ease with the language which typifies the speech of those who have been highly successful learners. Descriptors calibrated here include: convey finer shades of meaning precisely by using, with reasonable accuracy, a wide range of modification devices; has a good command of idiomatic expressions and colloquialisms with awareness of connotative level of meaning; backtrack and restructure around a difficulty so smoothly the interlocutor is hardly aware of it.

This level is the lowest level of generative language use - the point at which the learner can interact in a simple way, ask and answer simple questions about themselves, where they live, people they know, and things they have, initiate and respond to simple statements in areas of immediate need or on very familiar topics, rather than relying purely on a very finite rehearsed, lexically organized repertoire of situation-specific phrases.

This level is perhaps most categorized by two features. The first feature is the ability to maintain interaction and get across what you want to, for example: generally follow the main points of extended discussion around him/her, provided speech is clearly articulated in standard dialect; express the main point he/she wants to make comprehensibly; keep going comprehensibly, even though pausing for grammatical and lexical planning and repair is very evident, especially in longer stretches of free production. The second feature is the ability to cope flexibly with problems in everyday life, for example cope with less routine situations on public transport; deal with most situations likely to arise when making travel arrangements through an agent or when actually travelling; enter unprepared into conversations on familiar topics. 